$\mathbb{T}$ periodica polytechnica

Civil Engineering

$56 / 2(2012) 221+232$

doi: 10.3311/pp.ci.2012-2.08

web: http://www.pp.bme.hu/ci

(c) Periodica Polytechnica 2012

RESEARCH ARTICLE

\section{River - Groundwater Interaction over the Region of INFOPARK-Budapest}

\author{
Rózsa Csoma / Miklós Gálos
}

Received 2010-02-24, revised 2011-06-20, accepted 2012-02-28

\begin{abstract}
The region around the former Kopaszi-sandbank, a shallow, degraded part of the river Danube is now a dynamically developing district of the capital with a campus and the so-called INFOPARK. As the area itself was filled with various type of material during the last century, due to the prescription of the environmental authority regular control of the water quality parameters is introduced. Several groups of observation well were set to for the monthly observation of water quality parameters and the groundwater levels, as well. These levels are influenced by natural processes like the regime of the river or the precipitation, and by the buildings with foundations reaching the aquifer. The aim of this study is to show the interaction between the river and groundwater levels with special respect to the effects of buildings with deep foundations.
\end{abstract}

\section{Keywords}

groundwater $\cdot$ groundwater monitoring $\cdot$ the regime of the Danube $\cdot$ hydrogeology

\section{Rózsa Csoma}

Budapest University of Technology and Economics, Department of Hydraulic and Water Resources Engineering, H-1111 Budapest, Múegyetem rkp. 3., Hungary

e-mail: csoma@vit.bme.hu

\section{Miklós Gálos}

Budapest University of Technology and Economics, Department of Construction Material and Engineering Geology, H-1111 Budapest, Múegyetem rkp. 3., Hungary

e-mail:mgalos@freemail.hu

\section{Introduction and aim of the study}

Alluvial rivers usually influence the groundwater regime of the surrounding area. In municipal area other factors, as land covering may also play an important role, especially if the foundation levels of the buildings reach the aquifer. This problem is well known also in the capital of Hungary. In the earlier days the main aim was to ensure safe foundations and dry cellars, e.g. [12], nowadays beside the safety criteria of structures with several storeys above and below ground level e.g. [9], environmental questions have to be taken consideration, as well.

Such a bank area appears in the southern part of Buda, between the Petôfi and Lágymányosi bridges. Here the northern part is a campus of two universities, the Budapest University of Technology and Economics (BME) and Eötvös Loránd University (ELTE) and at the southern part, near the building of the Faculty of Electrical Engineering and Informatics of BME an informatics centre, the so-called INFOPARK-Budapest settled.

The area itself is strongly influenced by the river. In the beginning of the $19^{\text {th }}$ century, the width of the river was round the 300 $\mathrm{m}$ at the north, near the Gellért hill. South to this narrow part, at the area of the present $B M E$ the width sharply grew and between the present Petőfi and Lágymányosi bridges, the width already exceeded the $1000 \mathrm{~m}$. However, this extreme width was coupled with a rather shallow depth forming the so-called Kopaszisandbank. In the serious winter of 1837-38, the ice of the river filled almost the full section forming an ice jam that led to a catastrophic ice flood. Fig. 1 is based on the Navigation Map of the Danube [15]. It shows the present situation, but all the above-mentioned can also be followed on it.

Though some regulation conceptions were earlier introduced, this flood gave the final impulse for the reconstruction of the full flood protection system of the capital [14]. The main aim was to ensure a streambed with perfect flow conditions so that ice jam cannot form any more [6]. That is why to reduce the width a longitudinal rockfill dam was applied, as given in Fig. 2. The photo is taken by 1880 [25], so it shows the southern railway bridge alone. Later a road bridge is also built next to it and got the name Lánymányosi bridge. North to the bridge there is the Lágymányosi-lake that is already closed by the rockfill dam. 


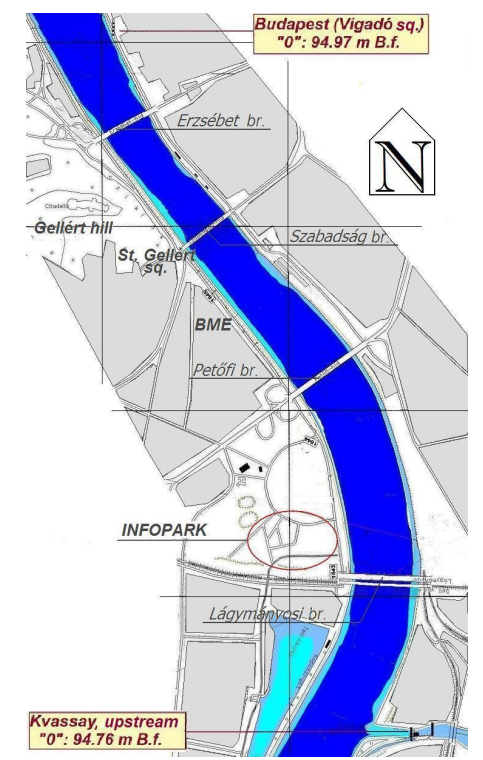

Fig. 1. Layout of the area

Petôfi bridge should be in the middle of the lake, but it is not on the picture, as it comes from a later time.

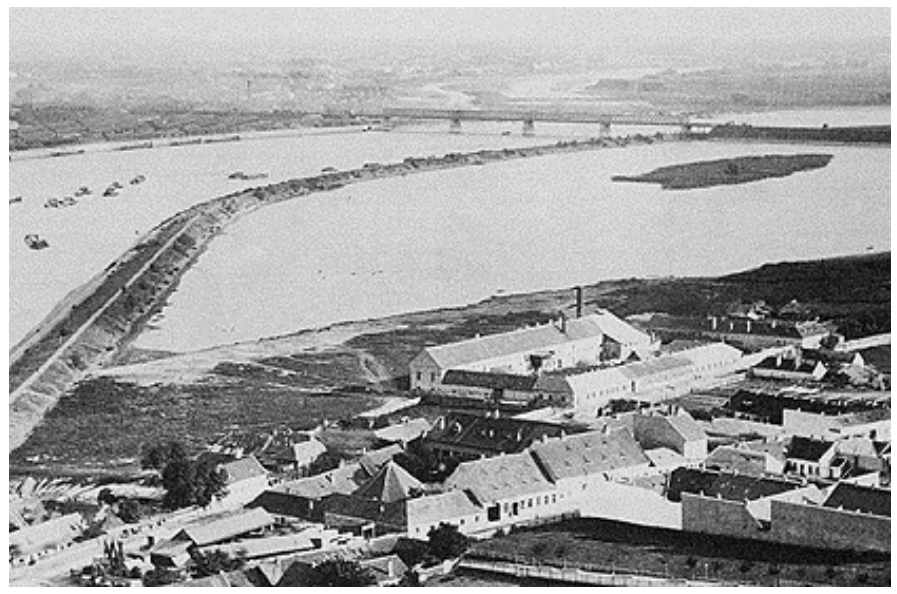

Fig. 2. Lágymányosi-lake by $1880 \mid 25$

To ensure even better flow conditions the left branch of the river south to this area was closed by barrages at both ends. This is how the right branch turned to be the main one with adequate capacity, as shown on Fig. 1. The closure at the upper end is called the Kvassay-barrage that consists of a navigation lock (1914.), water intake (1926.), and a powerhouse (1962) [8].

The construction of the longitudinal dam started from the north, and as soon as it was ready filling started behind it. The first buildings on the filling from 1901 belong to the university campus. The longitudinal dam reached the southern part in the last decades of the $19^{\text {th }}$ century. As the town grew, the longitudinal dam was rebuilt to a two-floor embankment. This can be seen on the next photo of Fig. 3 This is made after the First World War, as one can see the campus and Hotel Gellert in the front, but Petôfi bridge is still not on it [24].

The two-floor embankment is rather characteristic all over Budapest. The lower floor serves for boarding, the upper one for flood protection purposes [7]. The embankment near $I N$ -

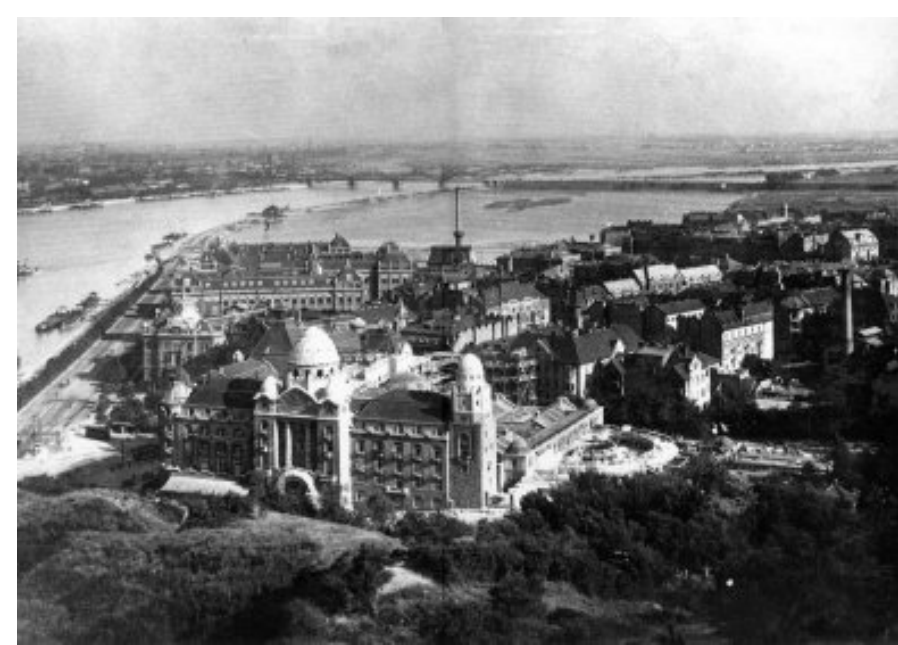

Fig. 3. The embankment at the $B M E$ campus 24

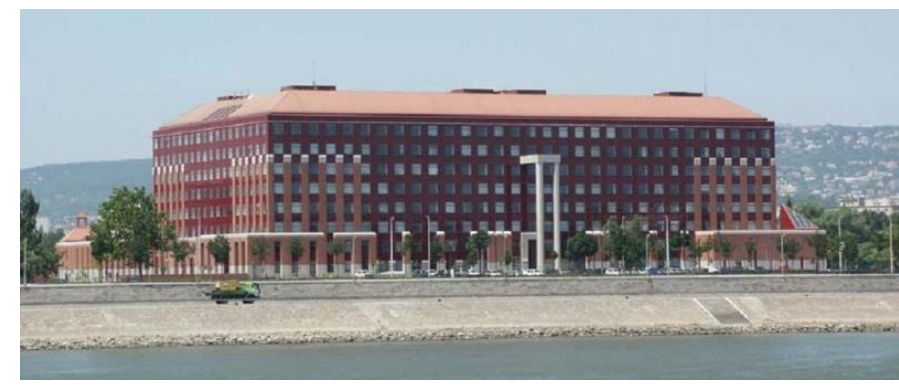

Fig. 4. The embankment at ELTE

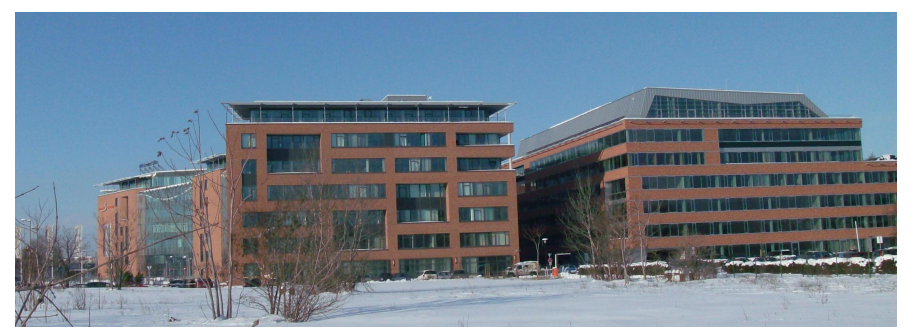

Fig. 5. Buildings $\mathrm{D}$ and $\mathrm{E}$ of INFOPARK

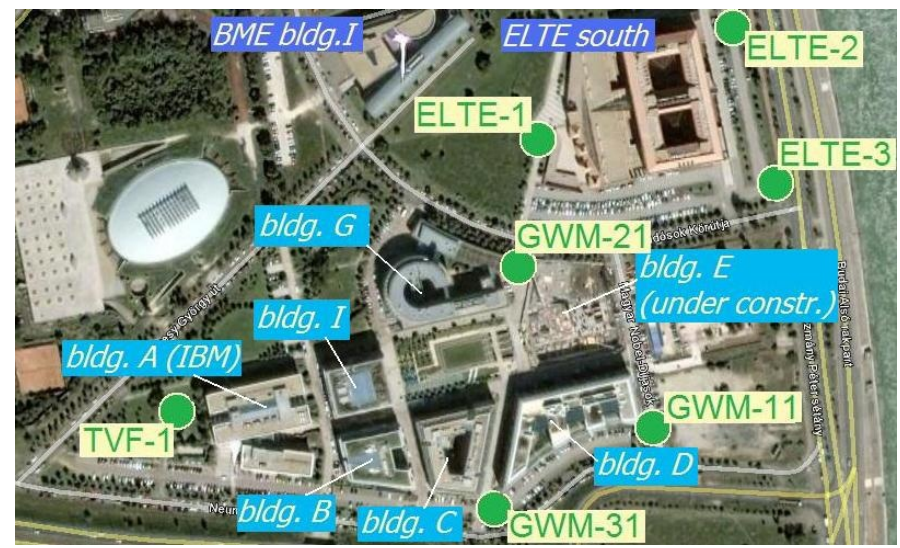

Fig. 6. INFOPARK based on $[19$ 
FOPARK, at the southern building of ELTE can be seen on Fig. 4 .

The filling of the area between the Petôfi and Lágymányosi bridges was finished by the fifties of the former century. Several conceptions were worked out for the development of the area. Finally, on the northern part, the campus of the $B M E$ was extended, and the Faculty of Science of ELTE joined. South, near the head of Lágymányosi bridge the Innovation and Technology Park, the so-called INFOPARK-Budapest settled. First building A (IBM) was ready in 1999, then G (MATÁV, 2000), B and I (2002.), C (2005.) and D (2007), forming a square. The last one, building $\mathrm{E}$ closes the square from the east [23]. It was finished while this paper was prepared. These last two buildings can be seen on Fig. 5

The layout of the full INFOPARK area together with the two southest university buildings can be seen on the photo of Fig. 6 that is based on [19].

The filling of the area is of rather mixed material, but the main component is slag coming from a nearby power station. This slag contains some heavy metal with a quantity sometimes exceeding health limit. To control the wash out of this dangerous material the environmental authority prescribed the construction and operation of several monitoring wells. So one well was set near the IBM centre and three other among the buildings of $I N$ FOPARK. This second group was relocated once, at the similar time, as three other wells around the southern building of ELTE were set. Though they are originally for water quality control, the levels are also recorded once in each month. All the seven wells are maintained and operated by Department of Construction Material and Engineering Geology of BME. They are read on the same day. The evaluation of the three groups is made yearly, independent of each other. So an overall evaluation of the three groups of wells together is just recently introduced.

The aim of this paper is to reveal the interaction between the groundwater levels of the independent groups of wells and the river Danube with special respect to buildings with deep foundations. Water quality considerations may be evaluated in a later work.

\section{Hydrogeological features of the area}

\subsection{Engineering Geological Features}

The geological development of the southern part of Buda, called Lánymányos is strongly connected to the Danube. Above a clay base, there is an extensive gravel - sandy gravel terrace. It is thicker near the river while behind a rise of the clay base it is rather thin. The eastern, thicker part is covered by natural debris and artificial filling and near the river only by filling. This can be followed on a geological section of Fig.7 that is based on the Construction-Hydrological Atlas of Budapest [13]. INFOPARK is fully lying on the filling.

The first geotechnical investigation on the area of INFOPARK was made by VITUKI [16]. Then while setting the monitoring wells, also a detailed evaluation of the different layers was

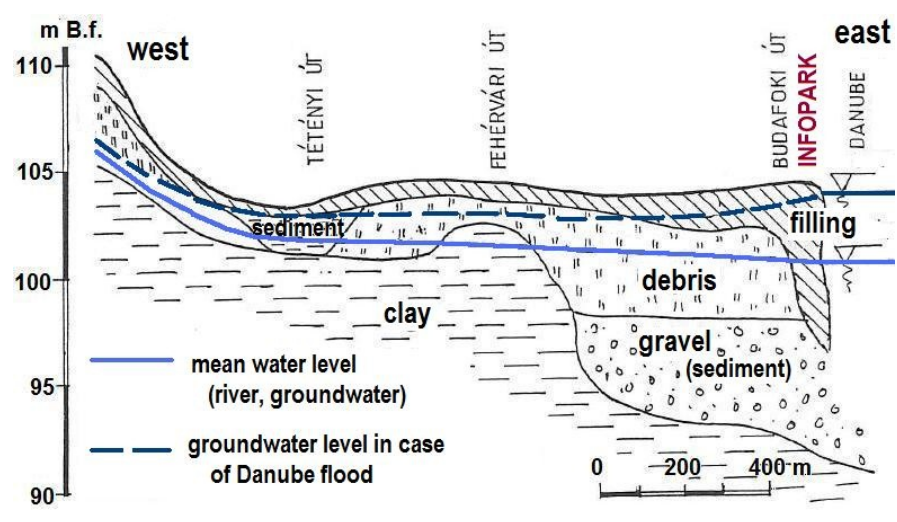

Fig. 7. Geological section

made. These proved that the base of the aquifer is clay, clayey marl below the bottom of the river. This can be considered as impervious. Above it, there is a gravel - sandy gravel layer of river sediment. It is $10-12 \mathrm{~m}$ thick and it has a relatively high permeability $\left(\mathrm{k}=10-10^{-3} \mathrm{~m} / \mathrm{s}\right)$. The next layer is a thin one $(1-2 \mathrm{~m})$ of silt that used to be the river bottom before the regulations mentioned earlier. It has a low permeability. Above it, there is the mixed filling with a thickness of $6-8 \mathrm{~m}$. The average ground level is $104 \mathrm{~m}$ B.f. Based on VITUKI's summary a geological section can be seen on Fig. 8 .

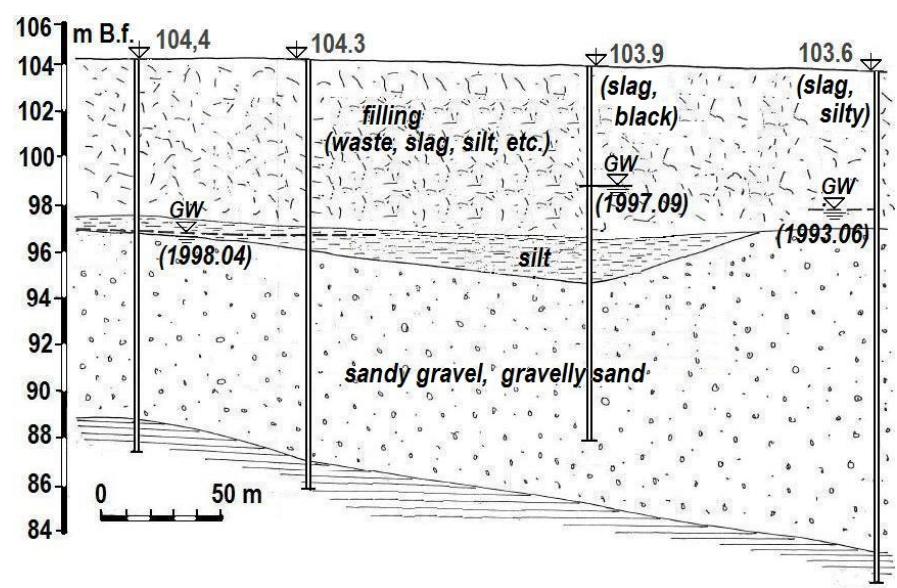

Fig. 8. The section of the aquifer

While the permeability of the aquifer is rather similar due to most of the sources, like [16-18,20], the permeability of the filling is rather different. Nevertheless, all of them show less permeable soil than the sandy - gravely aquifer. As the difference in permeability is at least one magnitude or even more, the filling can be considered as impermeable compared to the gravel.

\subsection{The Groundwater Levels}

\subsubsection{Earlier Recordings}

As the filling of the area continued until the middle of the 20th century, there is no long-term groundwater level observation over the area examined. That is why it is rather important to mention the work of Horusitzky from 1939 [5]. Though this time the area of the INFOPARK was still the Lágymányosilake, south to it, along the railway bed leading to the bridge (see Fig. 2) there were already monitoring wells. The observed 
maximum groundwater levels were here and a bit northern, near Petőfi-bridge 99 - 100 m B.f.

The earlier mentioned Construction-Hydrological Atlas of Budapest [13] already takes the effects of the Danube flood in 1965 also into consideration. This flood has the greatest duration ever recorded. Therefore, there is a rise of approx. $2 \mathrm{~m}$ in the maximum groundwater levels. Along the bank this rise is more than $3 \mathrm{~m}$, the maximum level reaches the $103 \mathrm{~m}$ B.f, which is near the maximum the river level. This can be seen in Fig. 9. which is a part of the map of maximum groundwater levels coming from the Atlas quoted before.

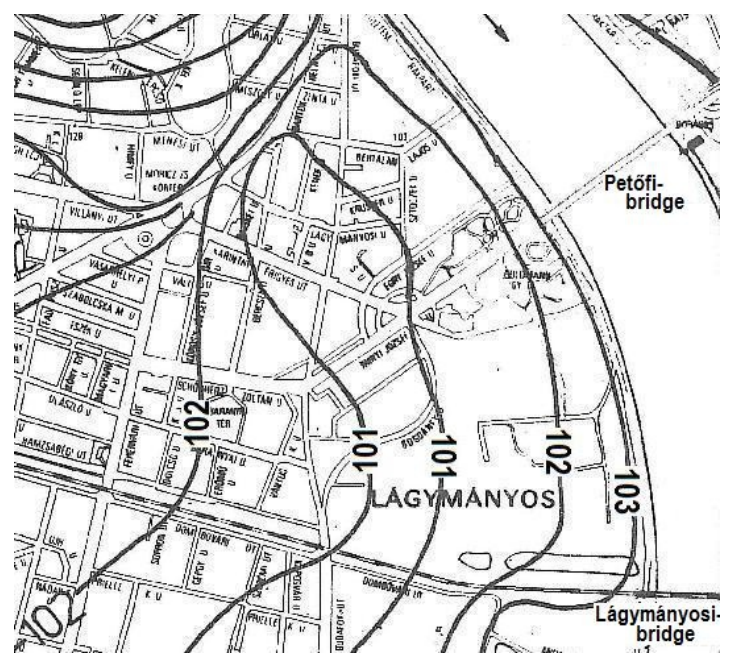

Fig. 9. Maximum groundwater levels (m B.f.) based on 13

\subsubsection{The Monitoring Wells}

North to Lágymányosi bridge there are three groups of observation wells, all together seven ones set. The first group of three wells called $G W M$ was set in 1999, and then the single one named TVF-1. Due to some modifications of the layout of some buildings, the group $G W M$ had to be relocated in 2003, so they have the number $11 \ldots 31$ from east to west [17,21]. At the same time, three more wells were set around the southern building of ELTE with the numbers 1 ...3 from west to east [18]. The layout is shown on Fig. 6

The wells were set under the protection of temporary steel casing. The permanent pipe is of PVC with the diameter of 125 mm, (except $T V F-1$ with $110 \mathrm{~mm}$ ). Each pipe is grouted. The length exceeds the $10 \mathrm{~m}$; the well screen is usually $5 \mathrm{~m}$. The wellheads are surrounded by concrete slabs, they are covered and locked (Fig. 10). While setting the wells, the borehole samples were widely evaluated [17, 18].

\subsubsection{The Evaluation of the Observations}

Due to the prescriptions of the environmental authority, the groundwater levels of the seven wells are observed and recorded monthly but evaluated only once a year. However, this annual evaluation is not accomplished at the same time for the three different groups of wells. The evaluation covers the comparison of the time series of the given group of wells, and the determination

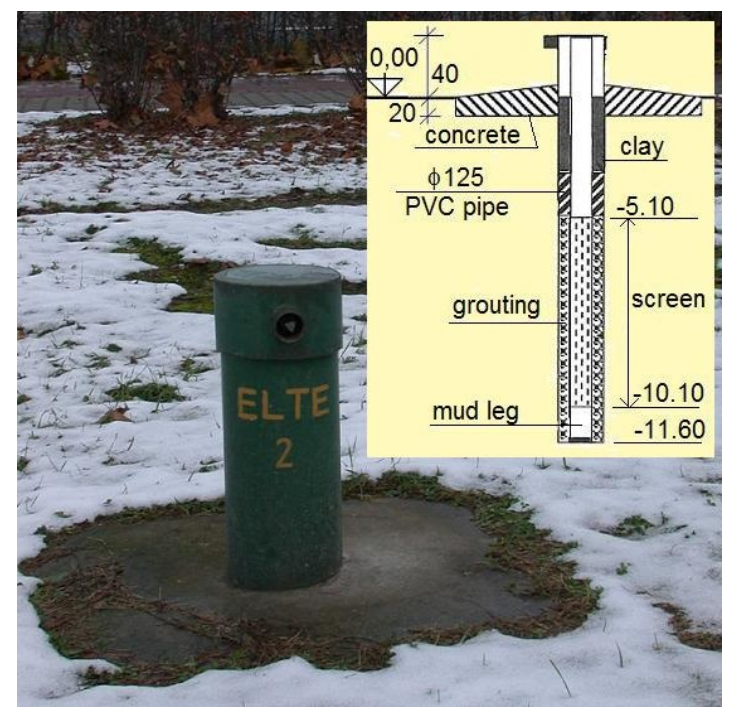

Fig. 10. An observation well

of the slope of the groundwater surface and the flow direction in some characteristic cases. This later cannot be given in case of the single well of $T V F-1$. Usually a characteristic case can be a long-term low or high water period. Such cases can be followed in the next figures. For the better comparison, each one is made for both groups of wells.

Fig. 11 shows the groundwater levels of May 2005. In this case, the Danube-level was slightly higher, than the long-term average. Part a./ of the figure shows the northern, ELTE-well field near the Danube, while part b./ is the southern $G W M$ wells (Fig. 6). Due to the relatively high level of the Danube there is a recharge of the groundwater, the flow direction is from the river, south - southwest, the slope is around the $0.10 \%$.

Fig. 12 shows the low water period of January 2006. This time there is a discharge from the groundwater to the river, the flow direction is almost perpendicular to the shore in both well fields. The slope is higher than earlier, around the $0.15 \%$.

Based on the recordings, the full time series for the period of January 1999 - July 2009 is given on Fig. 13. It also contains the river levels of the main gauge station of Budapest, Vigadósquare. The location of the gauge is given on Fig. 1. On the figure, one can follow the operation time of the groups of wells with the relocations, as well. Although the figure contains the full time series form 1999 on, the present examinations use only data from 2004 and later to avoid inhomogeneity coming from the relocation.

The regime of the individual wells follows the same pattern, which is strongly influenced by the river. Levels of ELTE-wells are usually lower, than $G W M$-wells. The lowest levels are observed at the most eastern, ELTE-3 well almost in the full period.

\subsection{The Levels of the Danube}

There are two main gauge stations of the Danube near $I N$ FOPARK. The northern one is at Vigadó-square with one of the longest time-series. The southern one is the upstream gauge at Kvassay river barrage nearer to the area examined. Both gauge 

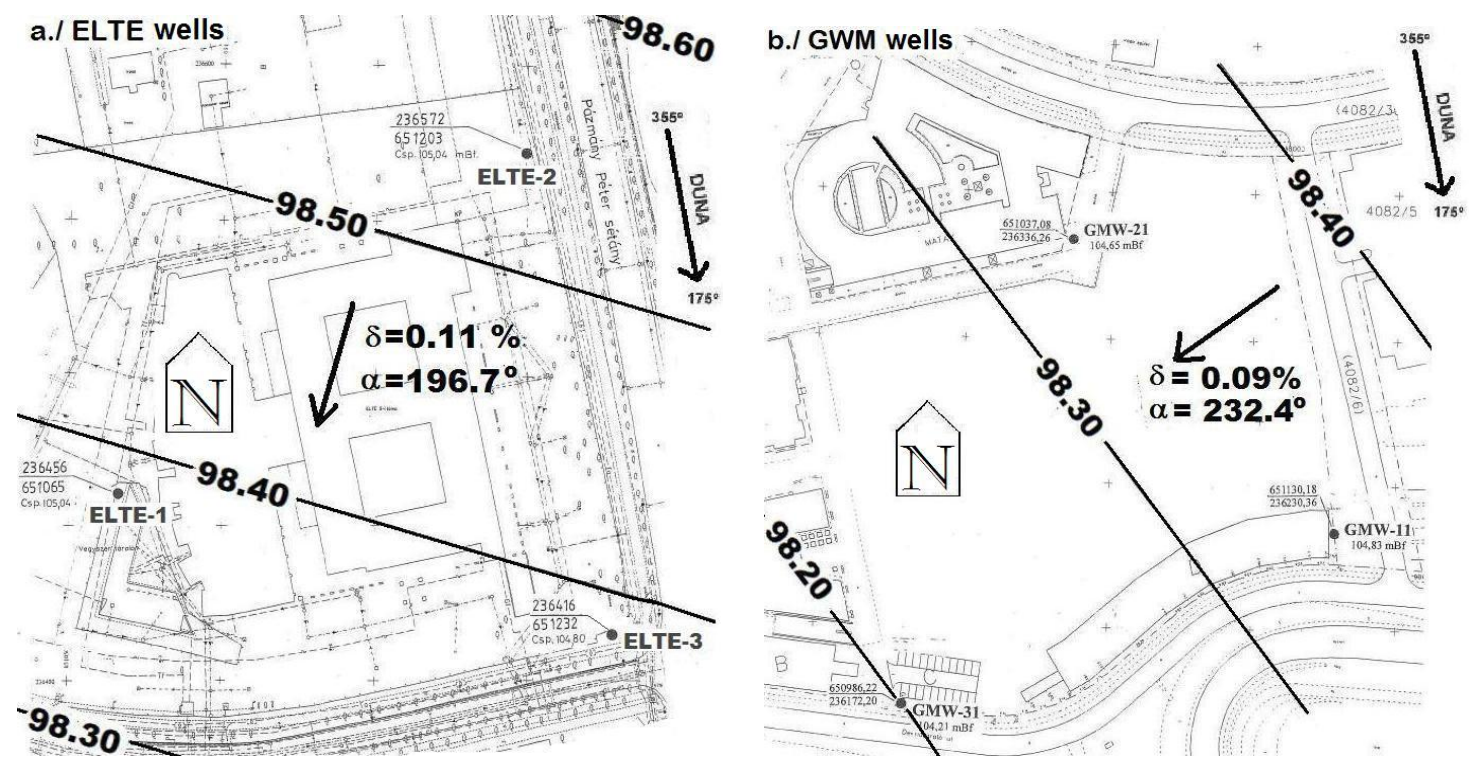

Fig. 11. Groundwater levels, May 2005
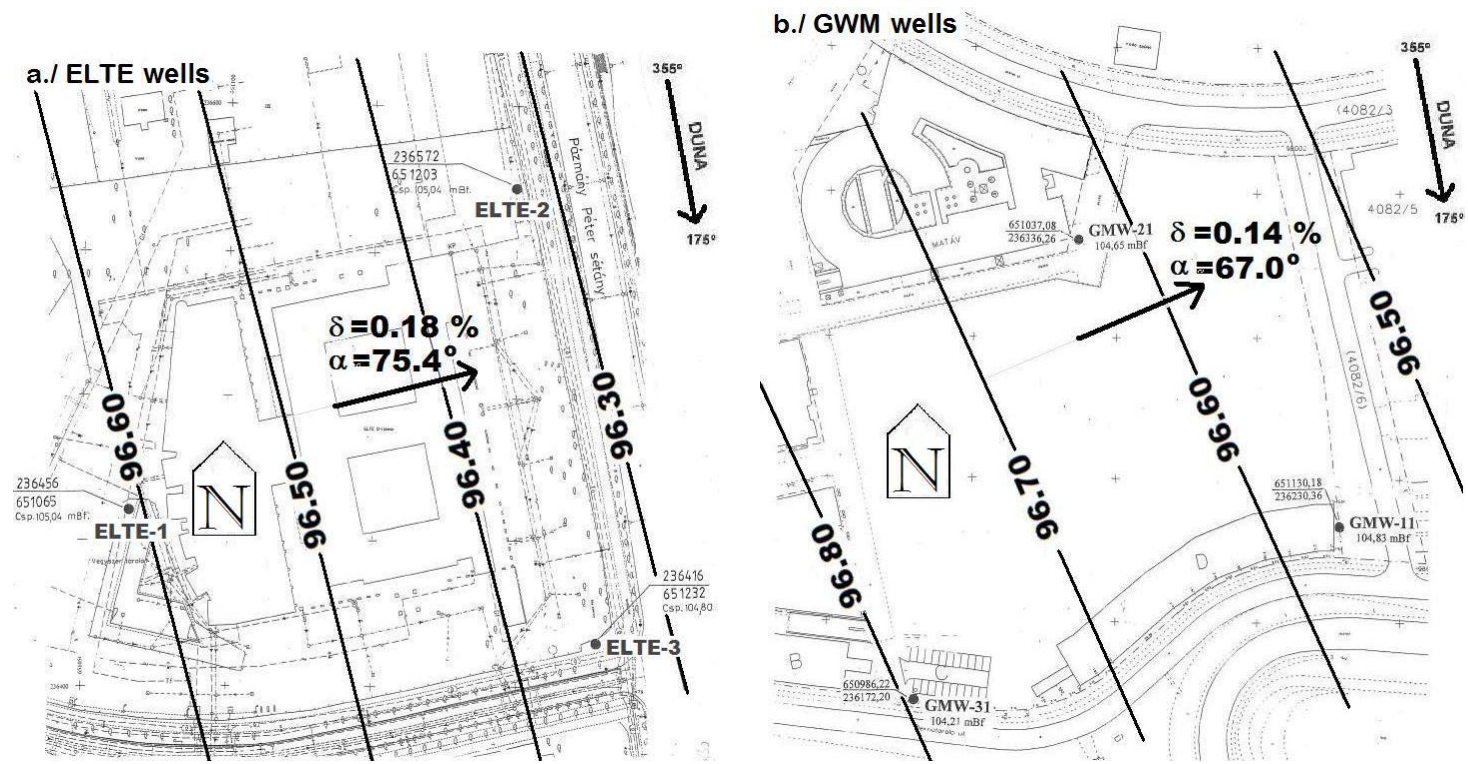

Fig. 12. Groundwater levels, January 2006

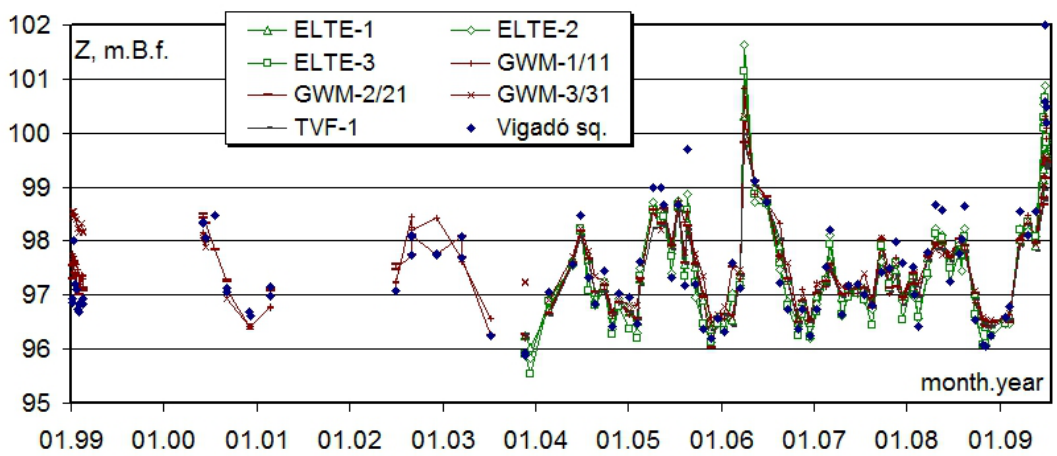

Fig. 13. Groundwater levels and the Danube level 
stations are indicated in Fig. 1, while the characteristic water levels are given in Table 1 .

Tab. 1. Maximum and minimum water levels

\begin{tabular}{ccc} 
& Budapest (Vigadó sq.) & Kvassay-barrage \\
\hline Location, km & 1646.5 & 1642.2 \\
\hline min, m B.f. & 95.48 & 95.24 \\
date, dd.mm.yyyy & 06.11 .1947 & 30.08 .2003$. \\
\hline max, m B.f. & 103.57 & 102.84 \\
date, dd.mm.yyyy & 04.04 .2006 & 04.04 .2006 \\
\hline
\end{tabular}

Figure 1 shows, that the gauge station at Kvassay-barrage is the nearer one to INFOPARK. This gauge is traditionally considered as a gauge on the Danube, but one can see, that it is actually on the Danube branch called Ráckeve-(Soroksári-) Dunaág (abbr. RSD). The one at Vigadó square is a real "Danubegauge", but it is a bit further. Due to the prescriptions, this upper gauge has to be reported together with the groundwater levels of the wells.

Based on the information of the Hydrographic Yearbooks [26] and on the online databases of HYDROINFO [22] and Hydrographic Databank [27], the daily water levels of the two gauges are given on Fig. 14. The period examined is January 1999 June 2009. As there was a flood at the end of June 2009 on the Danube, this time series is extended until the first decade of July. The time series covers almost the full range of water level variation at Vigadó square, and the full range at Kvassay-barrage. Table 1 show, that the flood of April 2006 provided the maximum at both gauges, and the extreme low water of August 2003 makes the minimum at one place and almost the lowest level at the other. These two extreme cases are marked with red ellipses of Fig. 14 .

It can be seen on Fig. 14, that there are some gaps in the time series of Kvassay-barrage. To fill it in, a curve of equivalent water levels of the two gauge readings was constructed and the missing data was estimated [3]. Then based on the two time series, water levels were interpolated at section $1643.3 \mathrm{~km}$ near INFOPARK, and a duration curve was also constructed. For the later examinations, this interpolated time series was used.

\subsection{Precipitation}

Precipitation may also influence groundwater regime. To reveal it two stations near the area of INFOPARK are taken into consideration. Based on the database of Hydrographic Databank [27] two stations are examined, the nearest, at Kvassaybarrage and an other one at the south, at Érd. The monthly sum of precipitation is given in Fig. 15. As there is some gap in both time series, only the period of January 2004 - June 2009 was examined. That covers the period of the operation of all the seven monitoring wells at the present location. However, the figure shows still some gaps remained in the beginning of 2004 .

The two stations show a parallel regime, though there are some exceptions, (e.g. December, 2005 or June, 2008) with extreme high precipitation at Kvassay-barrage. During the period examined the maximum was slightly over the $170 \mathrm{~mm}$ in August 2005 and the minimum is less, than $1 \mathrm{~mm}$ in April 2007 or May 2009. These extreme values are indicated with red ellipses on the figure.

\subsection{The Interaction of the Hydrological Parameters \\ 2.5.1 Danube-level - Groundwater level}

The main influencing factor of the groundwater seems to be the regime of the river. To demonstrate it the time series of the river levels at the section $1643.3 \mathrm{~km}$ near INFOPARK and the groundwater levels are given together in Fig. 16. In order to obtain a clear view, instead of the seven individual well recordings, the graph contains the average of the three groups of wells. It covers the period of January 2004 - June 2009, with an extension until the first decade of July due to a flood. One can see, that usually a low water with high duration is coupled with a low groundwater level, e.g. the autumn and winter of 2004 - 2005, 2005 - 2006 or 2008 - 2009, though the groundwater level is uniform compared to the river levels. These periods are indicated with red circles on the figure. Groundwater usually follows river levels in case of flood, as in April 2006 or June - July 2009, though floods with low duration appear in the groundwater damped and with a reasonable delay. These are indicated with orange ellipses on the figure. Moreover, there may be shorter periods, when the variation of the river and groundwater levels is the opposite, as in February 2005, indicated with light green.

Fig. 17 shows the flood of June - July 2009. In this case, not only the regular observations were accomplished on 29.06.09, but also five more readings were done. One can see, that the two wells nearest the Danube (ELTE-2 and 3) follow the river levels the best, though the double peak of river levels cannot be observed in the groundwater. The rising of the groundwater levels is smoother, but the drop is almost as sharp as the river. ELTE-1 at the back of the southern ELTE building follows the full process much softer. A sharper variation can be observed at GWM-11 at the east of INFOPARK. The reaction of the wells among the buildings is the smallest, especially $G W M-21$ and $T V F-1$ show only a gentle rising of the groundwater levels.

Similar processes can be followed on the next two figures, but in larger scale. Fig. 18 shows the connection between the Danube-level and groundwater levels at ELTE and TVF- 1 wells. Groundwater levels are given on the vertical axis, and river levels at the INFOPARK section are on the horizontal axis. Measured values of 2004 - 2009 are signed with marks, regression curve obtained with the method of least squares is indicated with different type of lines. As expected, the fitting is the best in case of the wells along the embankment (ELTE-2 and 3), like during the flood. The regression coefficient $\left(\mathrm{R}^{2}\right)$ is rather high, it is over 0.9. Such a good fitting cannot be obtained at any of the other wells. Nevertheless, even this high level of connection is not sufficient to estimate a kind of riverbed (or rather embankment) resistance neither as a constant value, nor as a function of any 


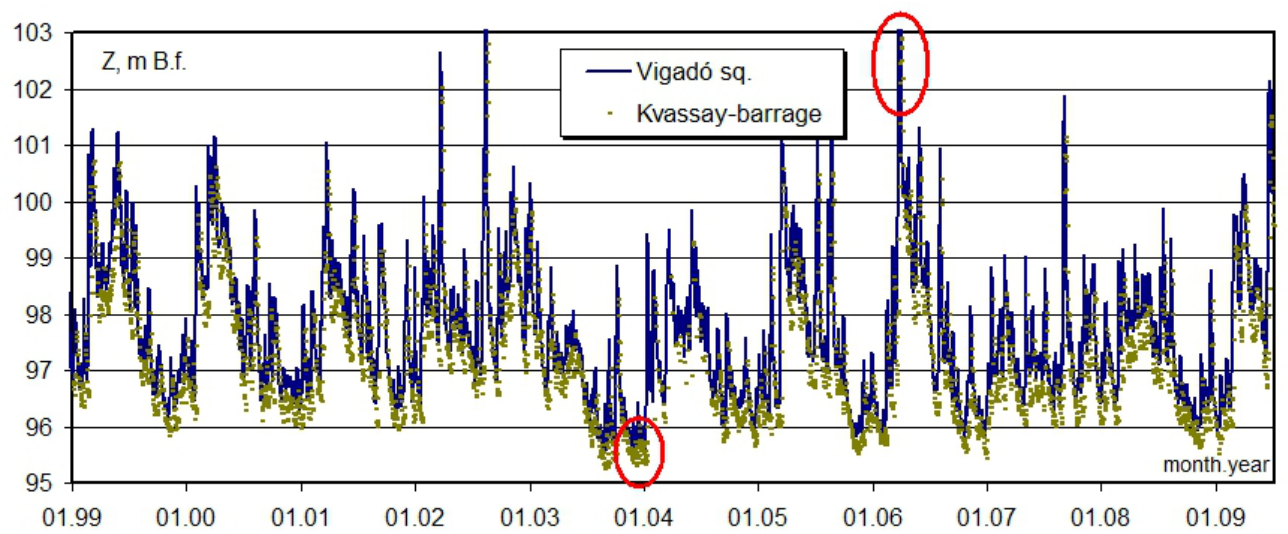

Fig. 14. Water levels at two gauge stations

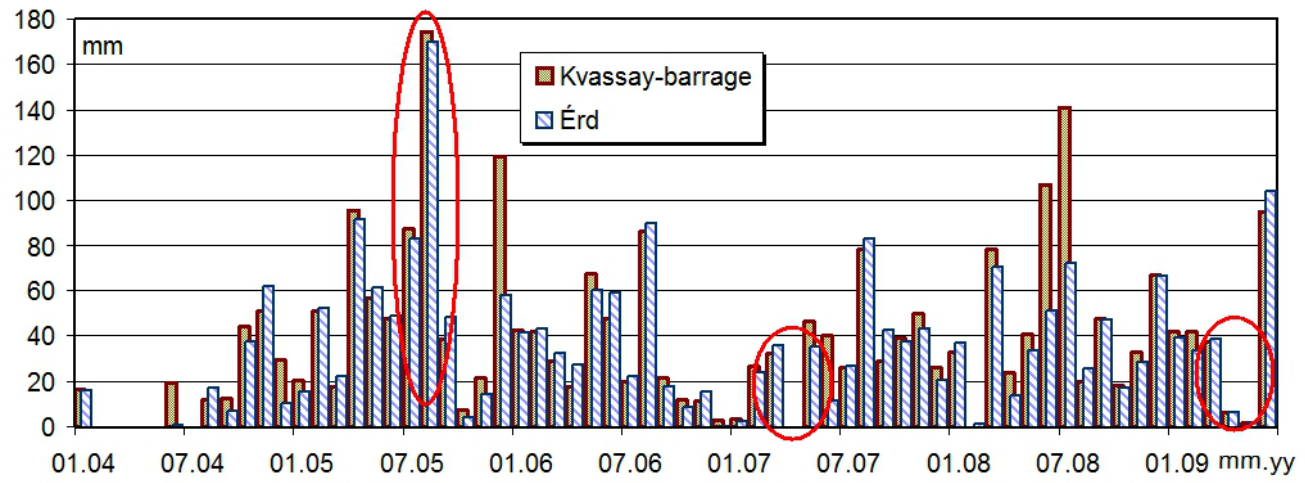

Fig. 15. Monthly sum of precipitation

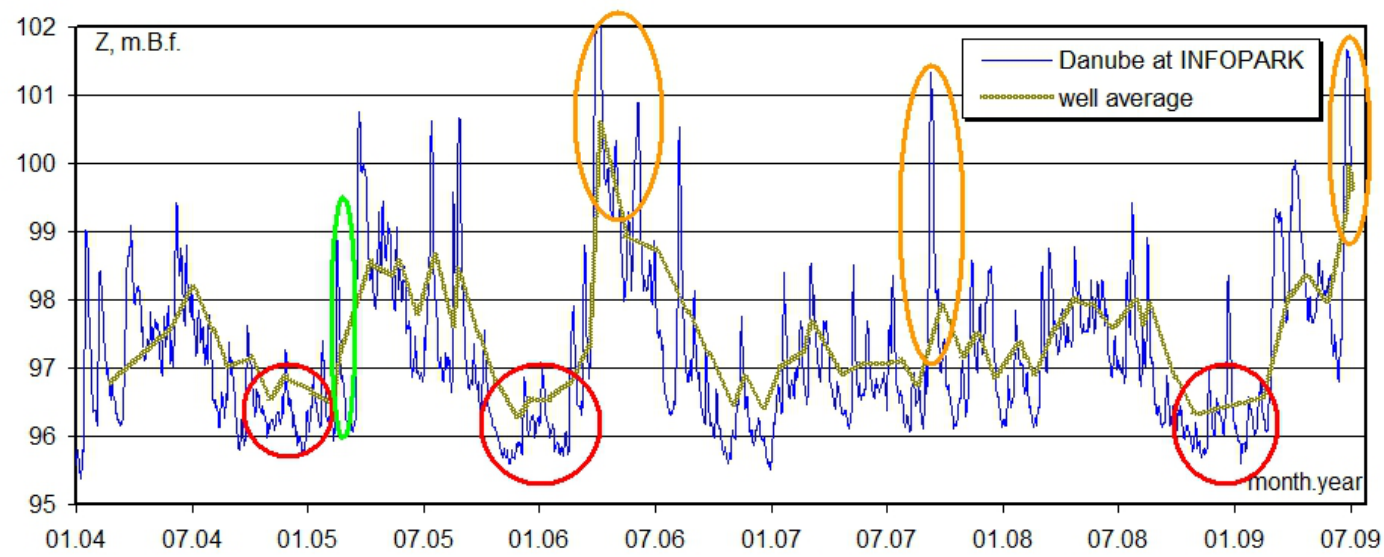

Fig. 16. The groundwater and the river levels

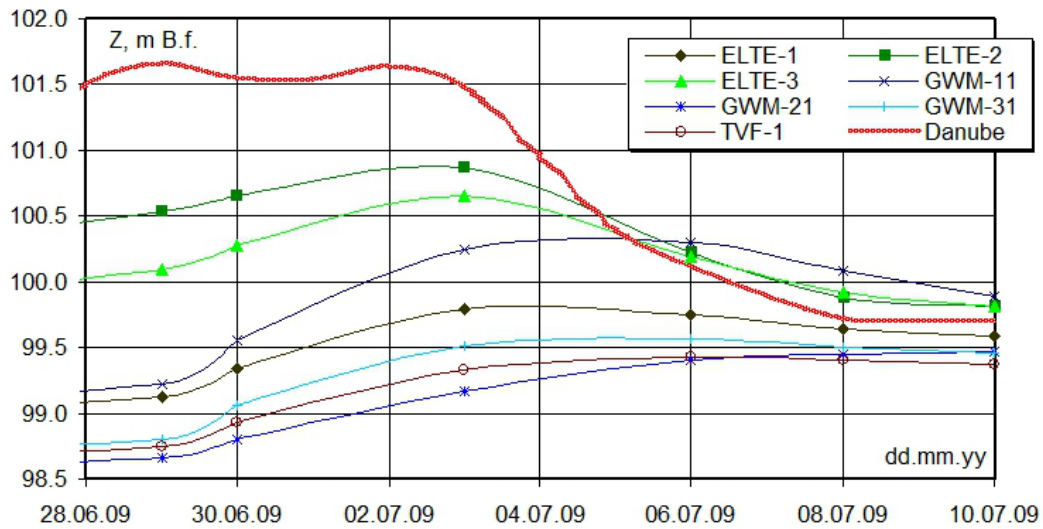

Fig. 17. The flood in June - July 2009 
water level. Therefore, there must be other influencing factor(s) in the river-groundwater interaction, as well.

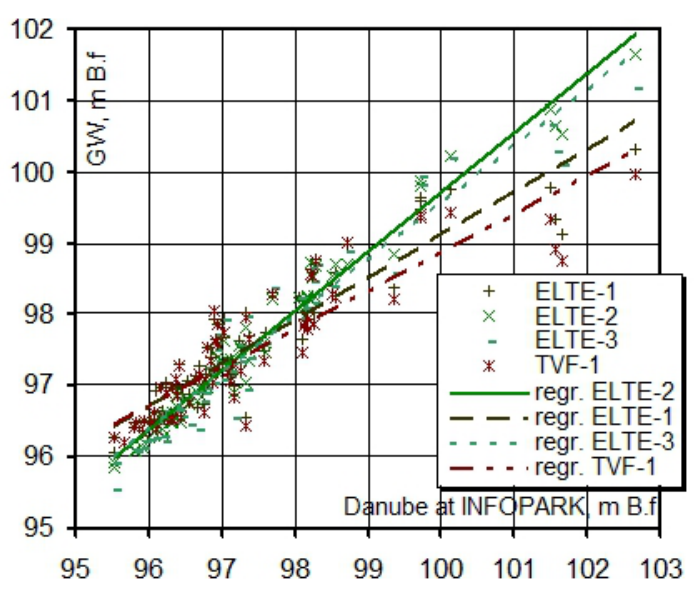

Fig. 18. Regression, Danube and the ELTE-wells

Fig. 19 shows the connection between the river and the GWM wells. Axes, scale and notation are similar to Fig. 18. It is clear, that the water level variation of these wells is smaller, but the scattering is higher. The connection between river and groundwater levels is rather poor, the regression coefficient is smaller, than 0.8. It is hard to explain, that the best fitting of $G W M-11$ nearest to the riverfront is similar to the fitting of $T V F-1$ behind all the INFOPARK buildings, at the very rear.

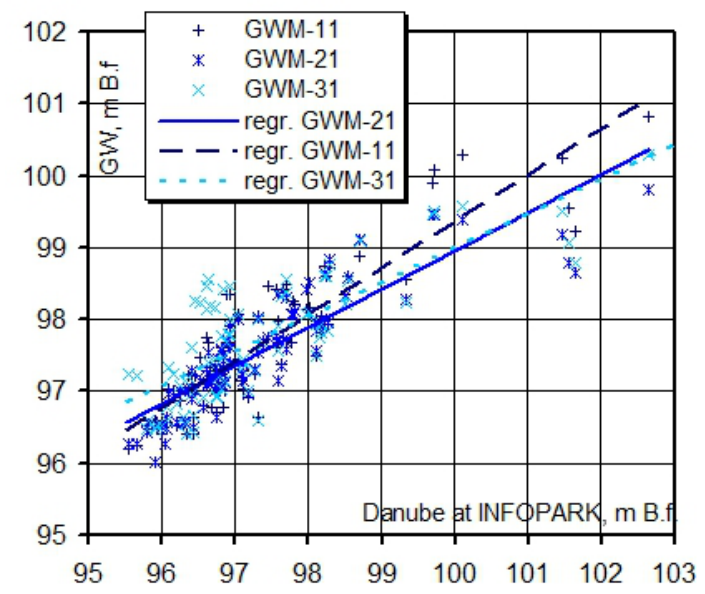

Fig. 19. Regression, Danube and the $G W M$-wells

Both figures indicate, that within the level range of 97.5 $98.0 \mathrm{~m}$ B.f. the flow direction changes. If the level is higher, the river recharges the groundwater. Based on the investigations mentioned in a former point its duration is around the $30 \%$. It means, that a direct recharge from the river can be expected during 3-4 month in a year. In the rest of the time, there is a drawdown in the direction of the river, when groundwater levels are also influenced by other factors, as precipitation, underground runoff, etc.

\subsubsection{The Connection Between the Precipitation and the Groundwater}

The groundwater level of the area examined is also influenced by the precipitation. Fig. 20 shows the variation of them. Both time series of the monthly sum of precipitation (right axis on the graph), and the observed water levels (left axis on the graph) are formulated as spatial averages of the two stations or the seven wells.

It is clear, that periods of low groundwater levels are connected to periods of low, or almost no precipitation, like the winters of 2004 - 2005, 2005 - 2006 or 2008 - 2009, indicated with red circles. On the other hand, its opposite, as high groundwater levels and high amount of precipitation cannot always be observed. For example in March - April 2006 there was a dry period, the high groundwater levels were definitely caused by the flood of the river. But the wet August 2005 with the highest precipitation of the period does not appear in the groundwater levels. The reason is, that this high monthly sum is due to a few days of extreme rain. The duration of it is too short for the groundwater to follow it. Both of the last two cases are indicated with orange ellipses on the figure.

\section{The effects of building density}

\subsection{The Aim and Method of the Examinations}

In the earlier points, the natural behaviour of the groundwater in the municipal region of INFOPARK Budapest was examined. But in case of a residential area, other, artificial effects may also play an important role. In this area especially buildings with deep foundation levels and garages has to be taken into consideration, but at other places underground railway lines and extensive stations, pedestrian subways, road tunnels or main sewers of large diameter may also influence the groundwater regime. And on the other hand, the dewatering of the building site and the seepage control of these structures may also formulate important questions during the construction or operation.

In the INFOPARK area the underground part of the individual buildings, characterised by the foundation levels is of major importance. If the foundation is not deeper than the filling of the area, i.e. $6-8 \mathrm{~m}$, it cannon reach the groundwater table, it forms no obstacle in the flow, so it has practically no influence on the flow. Such buildings of INFOPARK are A, B, C, G and I with the deepest parts of maximum $5 \mathrm{~m}$ below the ground level. But the southern building of ELTE, building D (2007) and the new building $E$ with garages below reach the depth of $11 \mathrm{~m}$, so they can influence flow conditions. The aim of this point is to estimate the extension and the effects of this influence.

For the detailed examinations characteristic periods without extreme conditions are needed, when steady state may be assumed. Such periods turned to be the ones already introduced in Point 2.2.3 The first one is April - May, 2005 with the Danube level higher, than mean water level, so the flow direction is from the river. This period is indicated with a single circle on Fig. 21 . The other one is the winter of 2005 - 2006 with a long term 


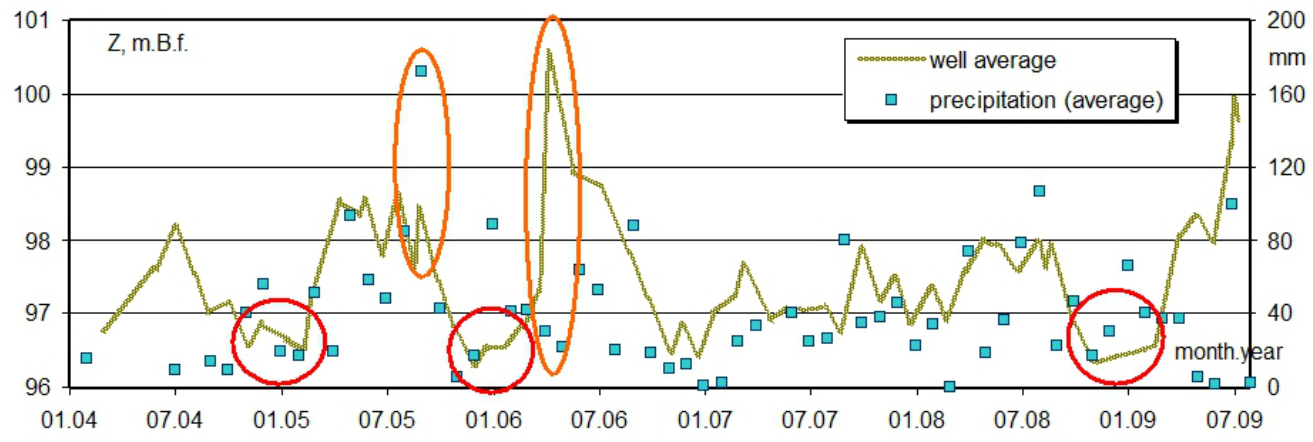

Fig. 20. Groundwater levels and the precipitation

low water in the river. This is signed with double circle on Fig. 21 As mentioned before, Figs. 11 and 12 show the observed groundwater levels of two certain days within this periods.

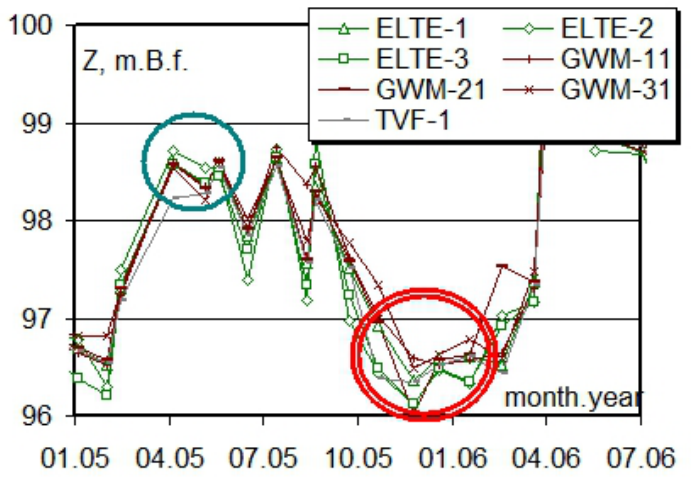

Fig. 21. Periods examined

Other advantage of these characteristic periods is that in this time only those buildings of INFOPARK were in operation which does not reach the aquifer, only ELTE south was ready by then. These buildings do not influence flow conditions. So it may provide an excellent base for comparison.

To describe the water regime a groundwater flow model in horizontal plane has to be built. That provides a regional description instead of the local information of the seven wells. Such a model can be applied not only for past situation, but for present or future, planned conditions, as well. The two characteristic cases mentioned before give the base situation, the present situation means if building $\mathrm{D}$ is also inserted to the model and the future can be described with building $\mathrm{E}$.

There are several ways of groundwater flow modelling with several modelling systems. For the present problem analytic element method (AEM) is applied. AEM is developed about 30 years ago by O.D.L. Strack [11]. It is based on the potential theory, but instead of the well known velocity potential, it uses its integral over the saturated aquifer, the so-called discharge potential. With the help of it, the simplified basic equation of steady groundwater flow turns to be the Laplace-equation with well known solutions.

The aquifer is subdivided into hydraulic units called the 'elements'. Each element represents one certain feature of the aquifer, like a river or a lake, the variation of aquifer parameters, infiltration, etc. The effects of each element may be described by harmonic functions. Based on the linearity of the governing equation, they can be superimposed to each other to give the full description of the aquifer.

There is a great variety of elements. Most of them are based on several well known flow pattern, and some are derived for specific problems. Below there is a brief summary of those that are used to describe the present area. More details may be found in several textbooks or other publications, e.g. [2, 4, 10,11], or in an earlier volume, e.g. [1], etc.

Cross flow describes far field conditions. Infiltration from the ground surface as a particular solution of the Poisson-equation can be approximated with ellipsis shaped equipotentials. It is also used to describe far field conditions.

The well-known potential of the source/sink describes wells. Line sink may be defined as the integral of it along a straight line. If the intensity is constant, it is of first order, while linearly varying intensity gives the second order line sinks. The first order one describes infiltration from smaller ditches with constant water level, while the second order one provides the description of rivers or streams with linearly varying water levels. An integration of the source/sink with constant intensity over an area gives the area sink. It is simple as a circle, but the integral over a polygon requires more efforts. However, it is a useful tool to model the infiltration from larger lakes, wider rivers, even of irregular shape.

The doublet is the resultant flow pattern of a source and a sink of the same intensity located at the same point. A doublet in cross flow can model the sudden changing of permeability. If a doublet is integrated along a line perpendicular to its moment, the line doublet is obtained. The string of it forming a closed polygon describes local inhomogeneities of aquifers, like the changing of the permeability or the step of base elevation or thickness. In case of smaller variations, the first order one is used, while sharper inhomogeneities are modelled with second order line doublets.

A given problem is always connected to a well defined region, though there are also several effects coming from outside. Most of the numerical models include these effects as boundary conditions. But the application of the potential approach considers an 
infinite plane without any boundaries. To limit this infinite plain and to take the outer effects also into consideration, around the area of interest a certain outer area has to be defined. This outer area provides a transition between the area of interest and the area left out of consideration. Its size, the elements to include or cancel and also the formulation of the included elements may be determined by calibration.

\subsection{Data Used for the Computations}

Data needed for the modelling is compiled as follows:

- The description of the aquifer is based on Point 2.1

- The layout and the levels of the Danube come from Point 2.3. It is modelled with different sets of line and area sinks.

- The layout and the foundation levels of the buildings come partly from [23], partly from the reports compiled while setting the different groups of wells [17, 18]

In the model, the buildings were considered as inhomogeneities of aquifer thickness. Such an inhomogeneity is taken into consideration as strings of second order line doublets of polygonal shape. The area of interest can be estimated as a rectangle bordered by the Danube from the east, the Lágymányosi bridge with its head and the adjoining roads from the south, the university sport grounds from the west and the green area between the two ELTE buildings from the north. But the full area considered is much larger, it covers also a longer part of the river on the north and south with the Lánymányosi-bay as well. Over this area a one-dimensional consideration of the river was sufficient, so it is described with line sinks, but within the area of interest due to the reasonable width a set of area sinks was needed.

For the model calibration and validation observed well levels of Point 2.2 were applied. After this, the base situations of May, 2005 and January, 2006 were modelled. Afterwards, building $\mathrm{D}$, then building $\mathrm{E}$ was inserted to the model both in the low and medium water case.

\subsection{The Effects of Buildings on the Groundwater Regime}

The flow conditions of May, 2005 can be seen on Fig. 22. The figure shows the rectangle of the area of interest in the Hungarian coordinate system, EOV. Observation wells are given on the figure with yellow. Though the slope of the groundwater table is rather small, it is clear, that the flow direction is already from the river.

Fig. 23 shows the same area, but in January, 2006. It can be seen, that the levels are $1.0-1.5 \mathrm{~m}$ lower, than on the former figure, the slope of the groundwater table is bigger and the flow direction is the opposite.

So the two characteristic cases are hydraulically opposite to each other. The next step is to insert buildings D then E into these two different flow fields.

In the low water period of January 2006, building D itself has almost no effects on the groundwater levels, and together with

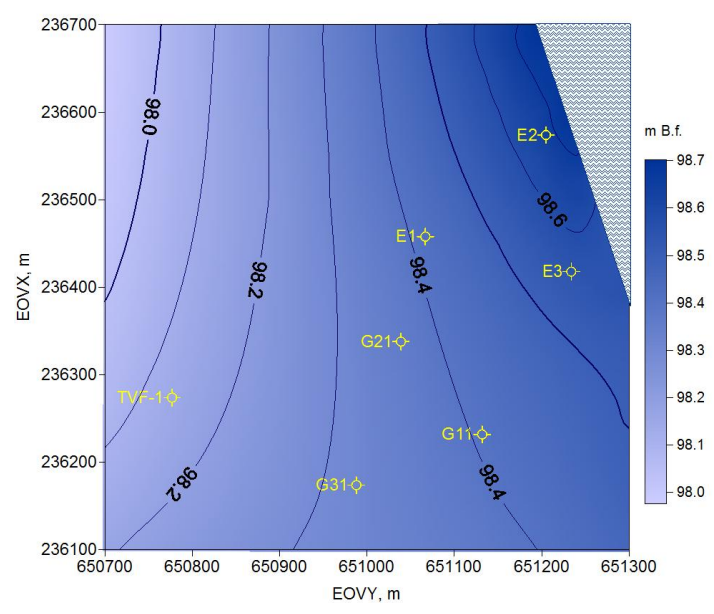

Fig. 22. Groundwater levels, May 2005

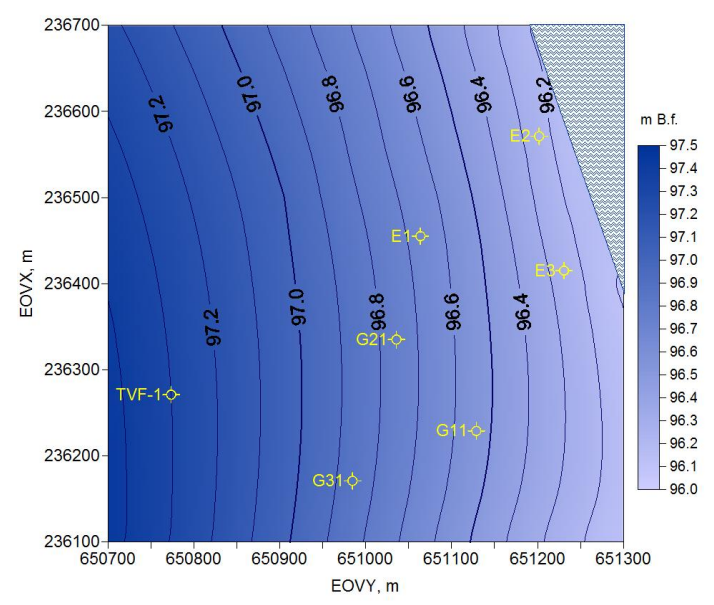

Fig. 23. Groundwater levels, January 2006

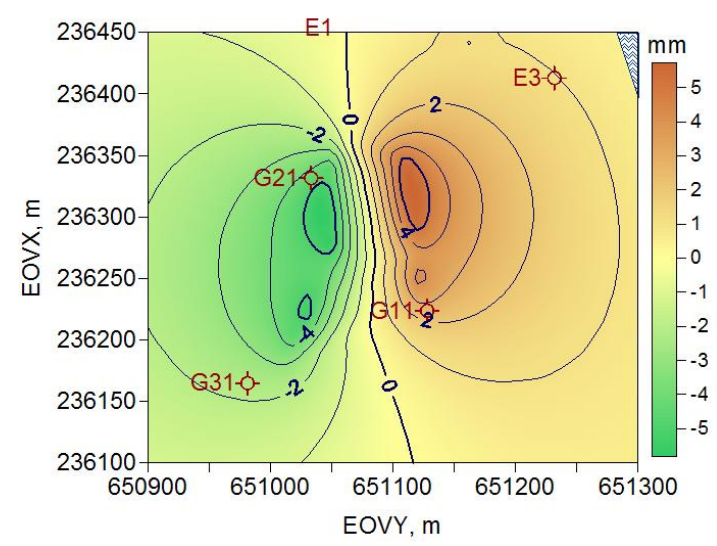

Fig. 24. Difference of groundwater levels due to buildings D and E, flow from the river 
the newest building E, the difference is still around the accuracy limits of the model. The slight difference may be explained with two reasons:

1. though the two buildings have almost the largest area of all the buildings, compared to the full area their extent is still relatively small;

2. the groundwater levels of $96.5-97.0 \mathrm{~m}$ B.f. are rather near to the foundation levels of around the $93.0 \mathrm{~m}$ B.f., so the relative changing of the aquifer thickness is small.

The situation is rather similar in case of May 2005. Though the groundwater surface lies slightly higher, the building density is still low. So a difference of a few millimetres may be observed near the buildings compared to the base situation. This is given on Fig. 24 that shows the southeastern part of the area examined. It can be seen, that the new buildings - as obstacles in the flow - cause rising of the levels in the direction of the Danube while behind these buildings the level is lower. Though the difference is rather small, the trends can be clearly identified.

But if the buildings form a continuous barrier in the direction of flow or the size and extent of the buildings reasonably changes building density or the foundation levels of the buildings reach the aquifer base and fully close the aquifer, then the differences really grow higher. As an example, it is assumed, that buildings $\mathrm{D}$ and $\mathrm{E}$ have a deeper garage, with two more floors below. In this case, the foundation level still does not reach the base of the aquifer, but the saturated thickness below the buildings is only $3 \mathrm{~m}$ instead of the original thickness of $10-$ $12 \mathrm{~m}$ (see Fig. 8). Fig. 25 shows the differences of groundwater levels compared to the base situation of May 2005. One can see that the lines of equal differences show the similar form, as on Fig. 24, but the variation is shaper, instead of a few millimetres, a few centimetres.

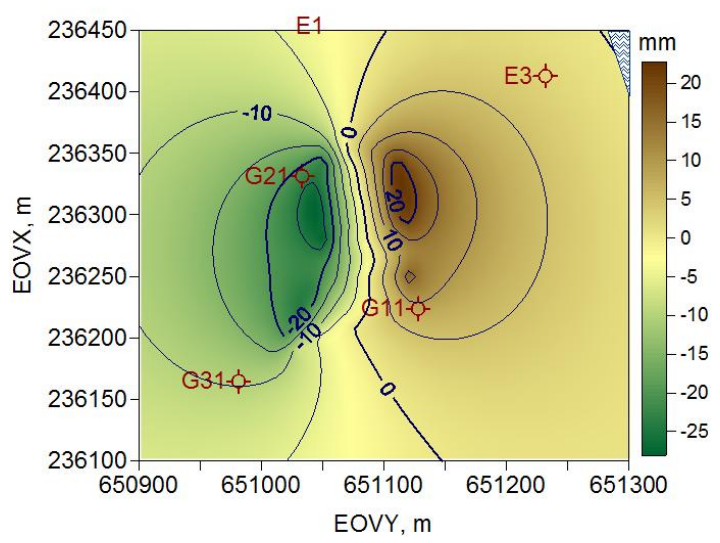

Fig. 25. Difference of groundwater levels with two extra floors below

So it can be stated, that presently these new buildings have no significant effects on the groundwater regime. But if either $I N$ FOPARK or any of the universities, or maybe any other investor starts new developments in the near neighbourhood of the $I N$ FOPARK buildings, careful investigations has to be performed do check the size, layout and foundation levels of the new buildings.

\section{Summary and conclusions}

Based on the careful evaluation of the data recorded at the groundwater wells of INFOPARK the following main results can be emphasized:

- The direction groundwater flow is strongly influenced by the river regime. Flow from the river to the area examined has a duration of $30-35 \%$, while the opposite direction, flow to the river has a duration of $65-70 \%$.

- The changing of the flow direction can be expected at the Danube-level of 97.5 - 98.0 m B.f.

- Groundwater regime is also influenced by precipitation, especially in long lasting dry periods, but short term extreme cases can hardly be recognized in the well levels.

- Buildings with the present foundation levels have almost no influence on the groundwater regime, as they are rather pointtype than linear and their foundation does not reduce aquifer thickness considerably.

As the observations still continue, the present work cannot be considered as a final evaluation. There are still several questions to answer at one hand, in connection with the local, INFOPARK region and at the other hand to set general conclusions that can be applied at other, municipal aquifers bordered by rivers. Some of the above mentioned questions are:

- The effects of building $\mathrm{Q}$ of $B M E$ that is nowadays under construction.

- The effects of the new main sewer that borders the area further from the west, along Budafoki street. This size of pipe as a longitudinal barrier may influence underground runoff from the west.

- The probable failure of the main sewer with a reasonable leakage may also be an important question to examine especially together with water quality considerations, as well.

- The extra readings during the flood in July 2009 proved to be really useful. Based on it readings of at least once in two days may be recommended. After several flood readings the filling - emptying of the aquifer during flood may be better understood.

- An other item can be the detailed examination including the full Lágymányos area that developed in the neighbourhood of the former Kopaszi-sandbank.

- Finally, based on detailed examinations of several similar area probably guidelines can be formulated to regulate building density with special respect to groundwater regime. 


\section{Acknowledgements}

Based on the assignment of GREENTECH Limited and GREENAREA Limited Partnership regular groundwater level observations on the well field of INFOPARK were accomplished by the staff of the Department of Construction Material and Engineering Geology of BME. Authors should like to express their special thanks to †István Tóth and Patrícia Tóth managing directors, and also to Endre Árpás and Gyula Emszt for the careful measurements and thorougfull documentation of the observations.

\section{References}

1 Csoma R, The Analytic Element Method for Groundwater Flow Modelling, Periodica Polytechnica Civil Engineering 45 (2001), no. 1, 43-62.

2 Csoma R, Szabályos és szabálytalan alakú analitikus elemek a talajvízmozgás modellezésére, $\mathrm{PhD}$ thesis, Budapesti Múszaki és Gazdaságtudományi Egyetem, Budapest, Hungary, 2007.

3 Csoma R, Gálos M, A Duna vízjárásának hatása a talajvízviszonyokra az INFOPARK-Budapest térségében, Mérnökgeológia - Kőzetmechanika 2008 (Török Á, Vásárhelyi B, eds.), Mérnökgeológia - Kőzetmechanika Kiskönyvtár, Múegyetemi Kiadó, Budapest, 2008, pp. 49-60.

4 Haitjema H M, Analytic Element Modelling of Groundwater Flow, Academic Press, San Diego, 1995.

5 Horusitzky $\mathbf{H}$, Budapest dunajobbparti részének (Budának) hidrogeológiája, Hidrológiai Közlöny (1939), no. special issue.

6 Ihrig D (ed.), A magyar vízszabályozás története, VIZDOK, Budapes, 1973.

7 Kertai E, Kozák M, Kővári L, Magyarország nagyobb vízépítési mútárgyai. Folyami kikötók, Országos Vízügyi Hivatal, Budapest, 1971.

8 Kertai E, Kozák M, Sárosi L, Magyarország nagyobb vízépítési mútárgyai. Vízlépcsók., Országos Vízügyi Főigazgatóság, Budapest, 1963.

9 Mecsi J, A Duna vízszintjének és a környezó területek talajvízszintjeinek kapcsolata, Mérnökgeológia - Kőzetmechanika 2007 (Török Á, Vásárhelyi B, eds.), Mérnökgeológia - Kőzetmechanika Kiskönyvtár, Múegyetemi Kiadó, Budapest, 2007, pp. 153-160.

10 Németh E, Hidromechanika, Tankönyvkiadó, Budapest, 1963.

11 Strack O D L, Groundwater Mechanics, Prentice-Hall, Englewood Cliffs, New Jersey, 1989.

12 Szabó Gy, Az 1965. évi dunai árvíz hatása a talajvízre a fớvárosban, Hidrológiai Közlöny 47 (1967), no. 12, 553-559.

13 Szenrirmay L-né, Retz R, Scheurer Gy, Budapest építéshidrológiai atlasza. M 1:20000, FTV, Budapest, 1988.

14 Töry K, A Duna és szabályozása, Akadémiai Kiadó, Budapest, 1952.

15 A Szob-Dunaföldvár közötti dunai hajóút kitüzési terve., Közép-Dunavölgyi Környezetvédelmi és Vízügyi Igazgatóság, Budapest, http://www. kdvkövizig.hu

16 Umwelttechnische und Baugrunduntersuchung auf dem Gelände Infopark Nord in Budapest, DHV Ingenieur-Consulting Deutschland GmbH, Bonn, 1998.

17 Budapest XI. kerületi Infopark 4082/21 HRSZ. alatti talajvízfigyelö kutak telepitése., GEOHIDRO Kft, Budapest, 2003.

18 Budapest ELTE TTK épületek déli tömb területén talajvízigyelö kutak telepítése., GEOHIDRO Kft, Budapest, 2003.

19 Google Earth., http: //earth.google.com

20 Informatikai Innovációs Park. InfoPark Budapest Északi terület. Földmunkák környezetvédelmi értékelése., GREENTECH Kft, Budapest, 1998.

21 Informatikai Innovációs Park. InfoPark Budapest Északi terület. Talajvízminôségi figyelókutak fennmaradási és üzemelési engedélyezési tervdokumentáció, GREENTECH Kft, Budapest, 2000.

22 HYDROINFO, Országos Vízjelző Szolgálat., Budapest, http://www. hydroinfo.hu
23 Infopark Budapest, IVG Hungary Kft, Budapest, http://www . infopark. $\mathrm{hu}$

24 Az Öböl - Újbuda - Lánymányos, Öböl XI. Kft., Budapest, http://www. obol.hu

25 Terasz. Online kulturális magazin, http://www . terasz.hu

26 Vizrajzi évkönyvek, 1996 - 2005, VITUKI, Budapest, 1996.

27 Vizügyi Adatbank., http: //www . vizadat.hu 